\title{
Inflation and Monetary Pass-Through in Guinea
}

Rodolphe Blavy 


\title{
IMF Working Paper
}

\author{
African Department \\ Inflation and Monetary Pass-Through in Guinea \\ Prepared by Rodolphe Blavy ${ }^{1}$ \\ Authorized for distribution by Francesco Caramazza
}

December 2004

\begin{abstract}
This Working Paper should not be reported as representing the views of the IMF. The views expressed in this Working Paper are those of the author(s) and do not necessarily represent those of the IMF or IMF policy. Working Papers describe research in progress by the author(s) and are published to elicit comments and to further debate.

The paper analyzes the dynamics of inflation in Guinea during 1992-2003 applying cointegration and error-correction modeling to a bivariate model that includes consumer price and monetary variables. The empirical results, based on quarterly data, confirm the existence of a long-run relationship between money supply and consumer prices. This paper argues further that the pass-through has increased in recent years. Short-term dynamics are shown to accentuate the long-run impact. Impulse response analysis shows that a shock in the money stock will have an increasing impact over two years and will then stabilize at a higher level.
\end{abstract}

JEL Classification Numbers: C32, E31, E52, O55

Keywords: Guinea, inflation, money supply, cointegration, error correction model Author(s) E-Mail Address: rblavy@imf.org

\footnotetext{
${ }^{1}$ I would like to thank Pierre van den Boogaerde, Mwanza Nkusu, Menachem Katz, Dennis Jones, Ezzedine Larbi, Ragnar Gudmundson, Kevin Cheng, Vivek Arora, Markus Haacker, and Nourredine Krichene for helpful comments; and Nathalie Baumer, Elisa Diehl, and Thomas Walter for editorial assistance. Finally, I would like to thank the Guinean authorities, in particular officials of the Central Bank of the Republic of Guinea, for their comments and interest in this research.
} 
Contents

Pages

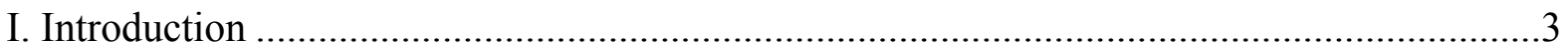

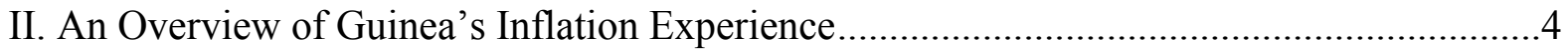

III. Composition and Structure of the Guinean CPI ................................................. 7

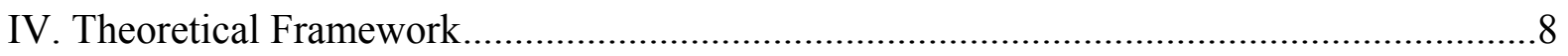

V. Long-Run Relationships Between Money and Inflation............................................

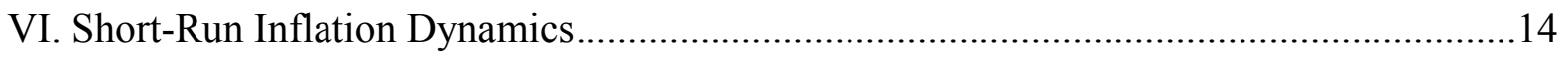

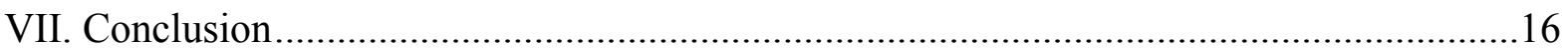

Appendix

Measures of Inflation and Early Signals in Guinea .................................................... 17

Tables

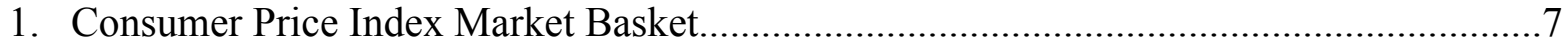

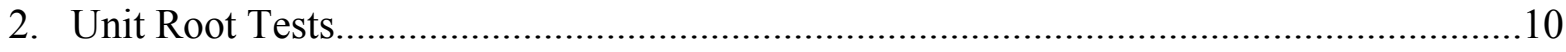

3. Long-Run Economic Relationships Between Money and Inflation.................................12

4. Structural Break Test (Chow Breakpoint Test).........................................................13

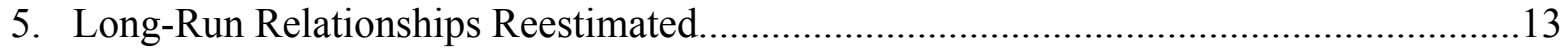

6. Vector Error Correction Estimates for D(LCPI) and D(LNONF)..............................14

7. Developments in the Overall CPI, January 2000-March 2003.................................. 18

Figures

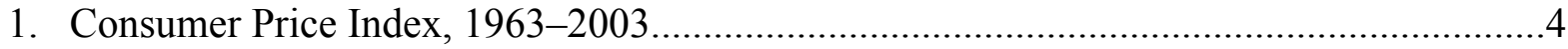

2. Consumer Price Index and Broad Money, December 1992-March 2003 .........................5

3. Consumer Price Index, December 1992-March 2003 .................................................6

4. Impulse Response Analysis on the Inflation Variables...............................................15

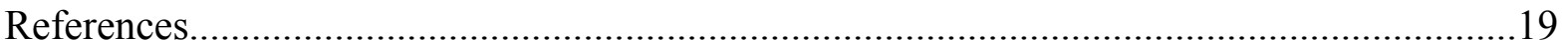




\section{INTRODUCTION}

Since October 2002, consumer price inflation in Guinea has been on a progressively increasing trend, reaching a peak of 16 percent year-on-year in May 2003. The importance of monetary developments in determining rates of consumer price inflation is often disregarded in light of the importance of exogenous factors such as the supply of food products. However, recent monetary developments suggest that increases in the money supply may indeed foster a resurgence of high inflation. Against this background, this paper develops stylized facts about the inflationary process in Guinea, focusing particularly on the relationship between money growth and inflation. To this end, we examine the influences of changes in money supply on consumer price index (CPI) inflation using quarterly data for the period September 1991-March 2003.

Owing to the lack of consistent time series, applications of long-run equilibrium models of inflation have been scarce in sub-Saharan Africa. The main contribution of this paper is to partly fill this gap by focusing specifically on Guinea for which no systematic study of the determinants of inflation is available. Data limitations suggest caution in interpreting the results. Recent developments in the country stress the relevance of our investigation. To provide evidence on the links between inflation and money growth, we build a bivariate inflation model containing monetary growth and CPI inflation. This methodology follows previous studies in applying cointegration techniques to the relationship between the price level and money supply (for example, Sacerdoti and Xiao (2001) for Madagascar, Kuijs (1998) for Nigeria, and Nachega (2001a and b) for Cameroon and Uganda).

The results point to a significant long-run relationship between money growth and consumer price inflation during the past ten years. There is also supporting evidence that the long-run relationship between the two variables has been reinforced in recent years. Using an errorcorrection model and impulse response analysis, we also find that a monetary shock has an immediate impact on inflation. The results support the argument in favor of an active monetary policy in order to maintain inflation at low levels. The analysis, by including, alternatively, broad money and reserve money variables, suggests that monetary policy may act in two related ways: (i) by direct liquidity management, to contain reserve money growth; and (ii) by a policy mix that does not lead to excessive broad money expansion in the economy.

The study may be useful for understanding the determinants of consumer price inflation in other African countries. In particular, the results show that, even with statistical weaknesses in the computation of the CPI and the large weight of food in the index, episodes of high money supply growth have a significant impact on CPI inflation, even if this impact is limited, given the role of exogenous factors, such as rainfall.

The remainder of this paper is organized as follows. Section II provides a summary of recent developments in CPI inflation. Section III discusses the composition of the Guinean CPI and other data-related issues. Section IV presents the theoretical framework of the model. Section $\mathrm{V}$ investigates the long-run relationship between money and inflation, while Section VI 
focuses on short-run dynamics. Section VII concludes the analysis and provides policy recommendations.

\section{AN OVERVIEW OF GUINEA'S INFLATION EXPERIENCE}

Inflation developments in post-independence Guinea may be roughly divided into three periods, as illustrated in Figure 1:

Figure 1. Guinea: Consumer Price Index, 1963 - 2003

(Annual percent change)

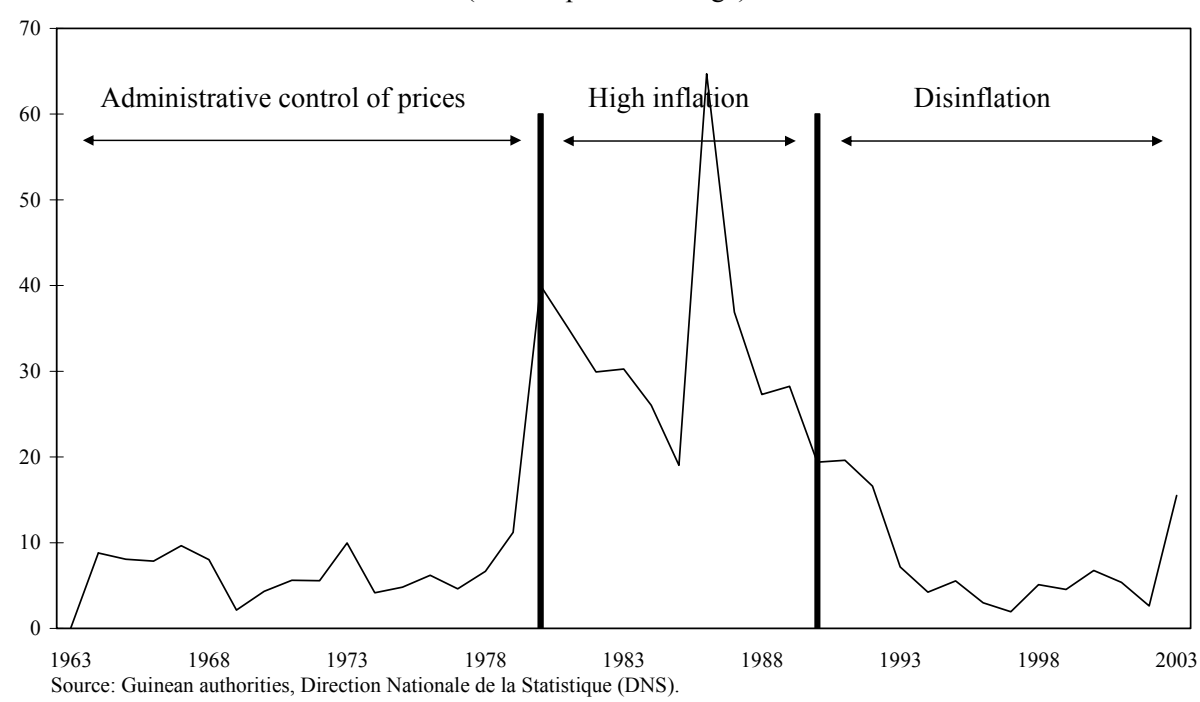

- In the first two decades after Guinea gained independence, inflation remained subdued at between 5 to 10 percent; it averaged 6.7 percent from 1964 to 1979 . Administrative controls distorted the operations of markets and the formation of prices.

- A prolonged period of high inflation followed, lasting for about 10 years from 1979 to 1989 . The surge in inflation in 1979 and the early 1980s was prompted by a partial economic liberalization in the context of significant fiscal imbalances and loose monetary policy, combined with weak supply responses. With the extensive reform program that followed the 1984 coup, inflation first increased dramatically, culminating in an annual average rate of 65 percent in 1986 when the national currency was devalued by 92 percent, trade was liberalized, and price controls (except those on fuel and rice) were removed.

- Finally, after 1986, the annual average rate of inflation dropped sharply and remained low until the end of 1999. Disinflation was supported by favorable climatic conditions leading to very significant increases in agricultural output and food production. Other improvements followed, including low price increases in food products and in basic commodities, particularly housing and transport; exchange rate stability; and a decline in imported prices, especially prices of imported rice (see Figure 1). Except in 1995, when elections and heavy rains pushed prices upward, the 
declining trend in inflation continued. Annual average CPI inflation was under 2 percent in 1997 and remained under control until 1999, largely because of the relative stability of monetary policy. Broad money growth was limited, bank credit to the government was contained, and the level of net foreign assets remained adequate.

The remainder of this section briefly surveys Guinea's recent inflation history and policy issues, with a specific focus on the link between inflation and the growth in the money supply. The current risk that Guinea faces - a return to a prolonged period of high inflationprovides the background for this study. Figure 2 depicts the behavior of prices and broad money over the past 10 years, using year-on-year growth rates. There are some clear stylized facts in the behavior of prices:

- Since 2000, the 12-month rate of change in the CPI has been volatile. A period of high inflation in 2000, driven mostly by a rise in nonfood prices (see Figure 3) was followed by a drastic reduction in the 12-month rate of CPI inflation, which reached 1.1 percent in December 2001. The rate of inflation remained below 3 percent until October 2002. Developments in the last quarter of 2002 and in 2003 showed a resurgence of inflation, which rose to 6.1 percent in December 2002 and 10.4 percent in March 2003, with a simultaneous increase in food and nonfood price indices. Volatility in money growth over the same period was even more marked, illustrating the consequences of "stop and go" economic policies.

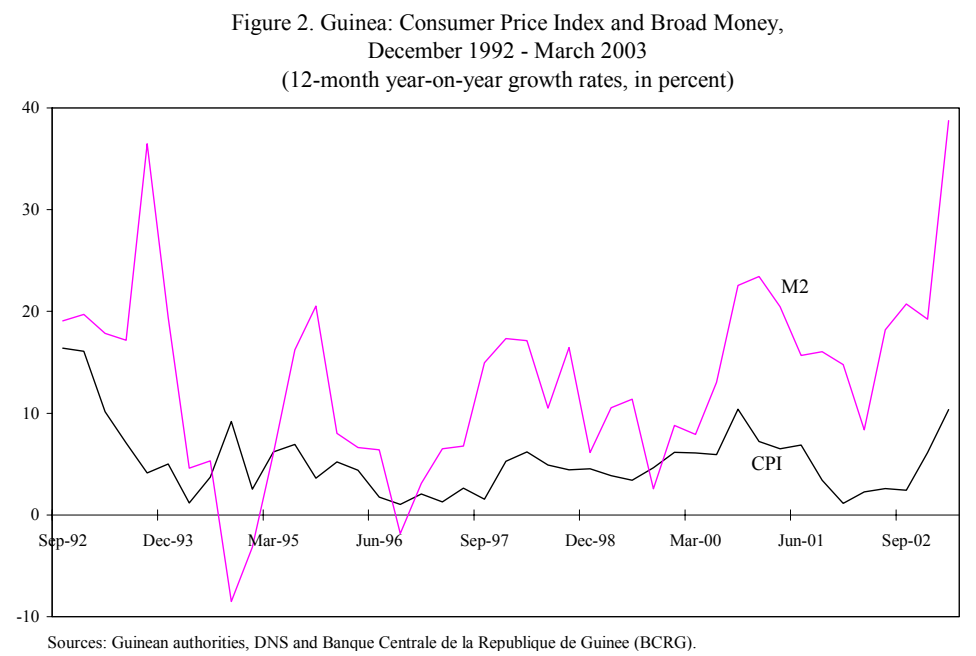

- Periods of rapidly rising prices have been associated with periods of monetary expansion. Policy slippages in 2000 resulted in increased inflationary pressures, as fiscal spending rose dramatically and as its monetary financing led to a significant monetary overhang. Twelve-month CPI inflation returned to double digits in the second half of 2000: it reached 10.4 percent, and remained around or above 7 percent until the last quarter of 2001, when fiscal discipline and monetary tightening eventually helped curb inflation. In late 2002 and in 2003, a substantial increase in base and broad money, in the context of rising credit to the government and falling net foreign assets of the central bank, was correlated with the resurgence of inflation. 
- The correlation between money growth and CPI inflation has grown over time, suggesting that the economy is becoming more sensitive to policy decisions and/or that demand shocks have been relatively more important, with little elasticity in domestic supply. This view is consistent with the fact that money growth in Guinea has been driven by the monetization of large fiscal deficits and large increases in public consumption.

Figure 3. Guinea: Consumer Price Index, December 1992 - March 2003
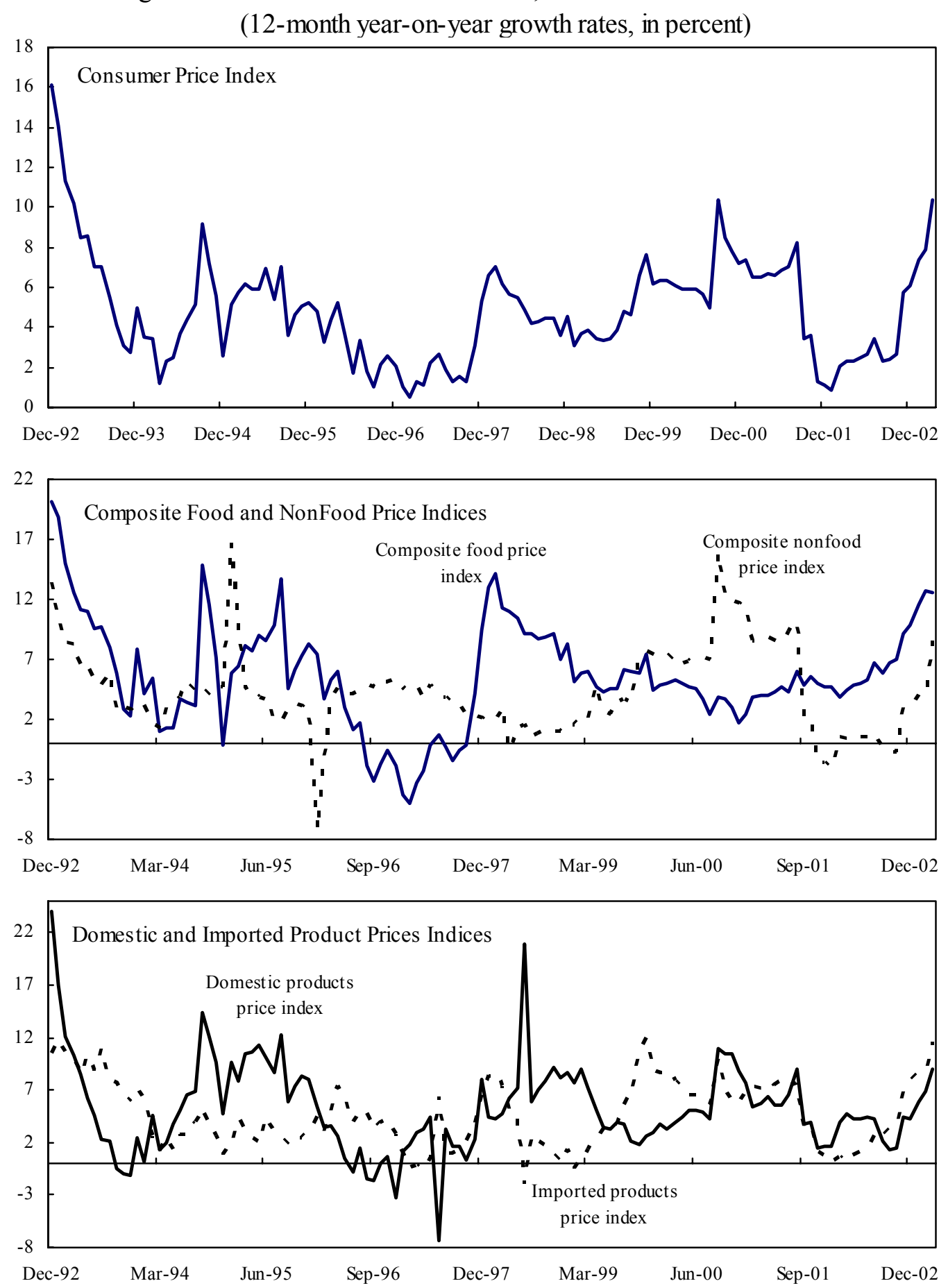

Source: Guinean authorities, DNS. 


\section{COMPosition AND STRUCture OF THE GUINEAN CPI}

The Guinean CPI has covered 165 items since 1987. The components and their weights in the CPI are summarized in Table 1. Food items account for a large proportion of the basket, which suggests that factors affecting food prices dominate movements in the CPI (see Figure 3). These factors include domestic inputs, costs of transporting food products to their retail markets, and climatic conditions, with rainfall playing a key role. In particular, the scarcity of food products between harvests frequently leads to tensions in domestic prices and to sudden jumps in the price level in the summer months, as illustrated in Figure 3. This same figure also suggests that domestic prices are more volatile than imported product prices, and weigh more heavily on CPI movements. In particular, the dramatic reduction in the rate of inflation until December 1993 was mainly driven by the decline in the prices of nontradable goods prices in the $\mathrm{CPI}$, while the decline in imported

Table 1. Guinea: Consumer Price Index Market Basket (In percent)

\begin{tabular}{lr}
\hline Commodity & CPI Weights \\
\hline Food & $\mathbf{4 1 . 9}$ \\
Nonfood & $\mathbf{5 8 . 0}$ \\
& \\
Clothing & 7.0 \\
Health & 9.3 \\
Housing & 15.1 \\
Electricity and water & 7.4 \\
Transport & 12.0 \\
Leisure and culture & 7.2 \\
& \\
All items & 100.0 \\
$\quad$ Domestic products & 58.9 \\
Imported products & 41.2 \\
\end{tabular}

Source: DNS, 2003 products prices was less marked.

A number of data weaknesses may be identified at the onset of the study. First, the index may be unrepresentative of consumption patterns. The weights (based on a 1991 survey) and some of the items composing the index may be obsolete. ${ }^{2}$ Further, information is being collected in five markets in different neighborhoods of the capital city of Conakry. Supermarkets and small retail shops, which account for a growing share of domestic sales, are excluded from the sample. Another limitation of the index, which covers only the city of Conakry, is the

\footnotetext{
${ }^{2}$ The index is frozen for some items that are not consumed in Guinea anymore: these account for more than 3 percent of the CPI. Also, the index does not capture new patterns of consumption - such as purchases of mobile phones, transport expenses, construction - and does not reflect substantial increases in the consumption of some food products, such as rice and potatoes.
} 
absence of a breakdown between urban and rural indices. ${ }^{3}$ In light of those weaknesses, there has been some concern that official figures probably do not reflect the actual rate of inflation.

The statistical relevance and accuracy of the various measures of inflation are additional issues, developed further in the appendix. In Guinea, outlier observations, often related to price jumps between harvests, tend to affect substantially the 12-month inflation growth rates. Measures of inflation may therefore be volatile. The use of quarterly data tracks the current developments in inflation better while smoothing the presence of noise in the data.

\section{THEORETICAL FRAMEWORK}

No systematic survey of the determinants of CPI inflation has yet been undertaken for Guinea, and this section proposes a theoretical model to explore the pass-through of money supply growth to inflation. Comparable studies for other African countries (Kuijs (1998), Sacerdoti and Xiao (2001), and Nachega (2001a and b) are used to derive an inflation equation to measure the impact of the relevant explanatory variables and predict the inflationary outcome of economic policy and exogenous factors. In a small open economy model with a flexible exchange rate, the price level is commonly postulated to be influenced both by money demand and by imported inflation.

The overall price level $(C P I)$ is a weighted average of the prices of domestic and imported goods. Prices of imported goods are determined exogenously in the world market and are valued domestically according to the level of the exchange rate. Given the limited availability of data and the shortness of the time series, the study focuses on domestic determinants of the price level. The price level is assumed to be determined by the equilibrium condition in the money market between real money demand and supply: $m^{d}=m^{s}$. Equation (1) specifies a long-term relationship in the money market.

$$
p=f\left[m^{d}-m^{s}\right] \text {, where } m^{d}=m^{d}\left(y, p^{e}, r_{d}, r_{f}\right)
$$

The demand for real money balances is determined by four variables: real income $(y)$, inflationary expectations $\left(p^{e}\right)$, and domestic $\left(r_{d}\right)$ and foreign $\left(r_{f}\right)$ interest rates. Money demand theory suggests in effect that the demand for real money balances is a function of the transactions demand (for example, real GDP) and of the opportunity cost of holding money (captured by inflation expectations and an appropriate domestic interest rate). ${ }^{4} \mathrm{An}$ increase in

${ }^{3}$ The authorities have acknowledged the urgent need to revise the CPI methodology used in Guinea, based on a 1995 survey of consumption patterns, and on the results of the poverty map to be established in 2003. The number of items in the index will be expanded to 317, and the weights for each item will be determined on the basis of a survey of 4,416 households, compared with 300 households for the current index. Overtime, coverage will be extended to all major urban centers in the country.

${ }^{4}$ See, for example, Mankiw (2003) for a presentation of money demand theory. Sriram (2000) surveys refinements made to the basic model. 
real income, expectations of a reduction in the rate of inflation, an increase in domestic interest rates, and a reduction in foreign interest rates will increase money demand and thereby lead to inflationary pressures. ${ }^{5}$

Two alternative bivariate models are considered: $z_{1 t}=\left[\Delta p_{t}, \Delta r e s_{t}\right]$ and $z_{2 t}=\left[\Delta p_{t}, \Delta M 2_{t}\right]$, containing monetary growth and inflation. Output and interest rate variables are not included in the model, because neither quarterly GDP data nor industrial production indices are available, and domestic nominal interest rates have been stable over time. Two monetary variables are used, corresponding to the narrowest (reserve money, res ${ }_{t}$ ) and the broadest (broad money, M2) monetary aggregates. We estimate a vector autoregression (VAR) model and apply cointegration tests to determine whether there are any long-run relationships among the variables. The analysis is based on an autoregression model of the form:

$$
\Delta x_{t}=\mu+\sum_{i=1}^{k} \Gamma_{i} \Delta x_{t-i}+\Pi x_{t-i}+\varepsilon_{t}
$$

where $x_{t}$ is the vector of the endogenous variables included in the model $(\Delta p, \Delta m)$; the parameters $\mu$ and $\Pi$ are allowed to vary without restrictions; $\mathrm{k}$ is the lag length of the model; and $\varepsilon_{t}$ is a vector of i.i.d. errors with a mean of zero and a variance of one. We test for the existence of a cointegrating relationship between the variables by analyzing the rank of the matrix $\Pi$ using the methodology developed by Johansen (1988).

\section{LONG-RUN RELATIONSHIPS BETWEen MONEY AND INFLATION}

The empirical analysis is conducted using quarterly data. End-of-period values are used, and all variables are in logarithms. To preserve the properties of the time series, they are not seasonally adjusted. ${ }^{6}$ The variables are as follows:

- Inflation variables: Because the Guinean authorities do not compute a core inflation index, the nonfood index $(N O N F)$ is used as an alternative to the composite CPI index $(C P I)$. A stronger relationship between money growth and nonfood inflation is expected a priori in the model because the composite index is more sensitive to exogenous events, such as geoclimatic conditions, and may give more weight to food products.

- Monetary variables: Two monetary aggregates are used alternatively: broad money ( M2) and reserve money (RES). Quarterly monetary data are available only from

\footnotetext{
${ }^{5}$ The independent role of geoclimatic conditions in influencing food prices, the impact of domestic petroleum price fluctuations, and the indirect impact of electoral spending during major national elections may also be substantial.

${ }^{6}$ Similar results were obtained with seasonally adjusted series.
} 
September 1991, restricting the sample for the model to September 1991March 2003.

Standard augmented Dickey-Fuller (ADF) unit root tests suggest that the variables are integrated of order 1, I(1): that is, they are nonstationary in levels while the first differences of the variables are stationary (see Table 2). As a result, and given that the two variables are considered endogenously determined, we proceed to formulate an unrestricted VAR model, with appropriate lags. ${ }^{7}$

Table 2. Unit Root Tests

\begin{tabular}{|c|c|c|c|c|c|c|}
\hline & Lags Included & $\begin{array}{c}\text { ADF } t \text {-Values on } \\
\text { Levels }\end{array}$ & Probability & Lags Included & $\begin{array}{l}\text { ADF } t \text {-Values on } \\
\text { First Differences }\end{array}$ & Probability \\
\hline$L C P I$ & 2 & -3.070 & 0.126 & 1 & -6.127 & 0.000 \\
\hline$L N O N F$ & 0 & -3.403 & 0.064 & 4 & -3.636 & 0.039 \\
\hline$L M 2$ & 1 & -1.332 & 0.867 & 0 & -3.239 & 0.090 \\
\hline LRES & 1 & -1.579 & 0.786 & 0 & -9.649 & 0.000 \\
\hline
\end{tabular}

Notes:

The ADF is the augmented Dickey-Fuller test. The null hypothesis is a series containing a unit root.

The number of lags was determined automatically based on the Schwartz Information Criteria (SIC).

The reported statistics are for the tests with a constant term and a linear trend included.

The Johansen methodology is used to test the presence of a cointegrating relationship. ${ }^{8}$ Two sets of results are reported, the trace statistics and the maximum Eigenvalue test, both of which indicate whether the hypothesis of cointegration between the variables should be rejected. Economic theory should then be used to place restrictions on the model and identify the long-run equations. Given the paucity of data in Guinea, long-run equations, in the form of the money demand equation defined above, may not be fully identified. Variables such as real income, and domestic interest rates are not available for the period under study. Caution should therefore be exercised in the interpretation of the identified long-run relationship between the price level and monetary aggregates. The coefficients may represent only partially the extent of the relationship, and an omitted variable bias may affect the coefficients. The results of the cointegration analysis are presented in Table 3 . The VAR

\footnotetext{
${ }^{7}$ The appropriate lag length is chosen based on the basis of the results of lag exclusion tests, and on the basis of the various lag length criteria computed in e-views, including the sequential modified $L R$ statistic, the final prediction error, the Akaike information criterion, the Schwartz information criterion, and the Hannan-Quinn information criterion.

${ }^{8}$ The existence of a cointegrating relationship is tested by analyzing the rank of the matrix $\Pi$. If the coefficient matrix $\Pi$ has reduced rank $\tau<n$, where $\mathrm{n}$ is the number of endogenous variables, then there exist $k \times \tau$ matrices $\alpha$ and $\beta$, each with rank $\tau$ such that $\Pi=\alpha \beta^{\prime}$ and $\beta^{\prime} y_{t}$ is $\mathrm{I}(0) . \beta$ contains the cointegrating vectors, and the elements of $\alpha$ are known as the adjustment parameters in the VEC model, that is, the coefficients of the errorcorrection terms or the speed of adjustment to the long-run equilibrium.
} 
model consists of the appropriate lags on the endogenous variables, with a term trend, restricted to lie within the cointegration space. ${ }^{9}$ In all four models, the hypothesis of no cointegration between the endogenous variables is rejected, and one long-run relationship is identified between the price level and money at the 5 percent level of confidence.

The four long-run relationships may be written as follows:

$$
\begin{aligned}
& L C P I=0.317 L M 2+0.004 \text { Trend } \\
& L C P I=0.477 L R E S+0.004 \text { Trend } \\
& L N O N F=0.257 L M 2+0.004 \text { Trend } \\
& L N O N F=0.160 L R E S+0.007 \text { Trend }
\end{aligned}
$$

The model performs well in explaining the price level as a function of money, suggesting that increases in the money stock have a substantial long-term effect on inflation. ${ }^{10}$ The impact of reserve money on the composite CPI is larger than the impact of broad money, reflecting the role of currency in circulation in determining CPI inflation. Currency in circulation accounts for around 80 percent of reserve money and only around 55 percent of broad money. ${ }^{11}$ The larger impact of reserve money on the composite CPI is thus not surprising, given the large weight of food prices in the CPI and the direct impact of currency in circulation on food prices. The results on the nonfood price index confirm the analysis, with (i) the impact of monetary variables being more subdued, ${ }^{12}$ and (ii) broad money having a larger impact than reserve money on the nonfood price level. In addition, the coefficients of the money variables are lower than could be expected, suggesting that a doubling in the money supply results in a price increase of only about 16 to 48 percent. Two explanations may be given for the low

\footnotetext{
${ }^{9}$ Alternative specifications have been explored, in particular models with a constant, with and without a time trend. The results are not reported here and are broadly similar to those presented. The model proposed here is retained because it provides the strongest cointegrating relationship between the variables.
}

${ }^{10}$ Results of the pair-wise Granger test of causality reinforce the findings that money and inflation are to be treated as endogenous variables. However, the Wald statistic is lower for the inflation variable in the money equation, suggesting that the direction of causality does, indeed, run from money to prices.

${ }^{11}$ Given the close correlation between reserve money and currency in circulation, results obtained using the currency in circulation variable are similar to those obtained with the reserve money variable and are therefore not reported here.

${ }^{12}$ One possible explanation for the more subdued impact of monetary variables on the nonfood CPI is the absence in the model of variables accounting for the changes in the nominal exchange rate and for other import price shocks. However, the results obtained after inclusion of the nominal exchange rate in the model provided insignificant coefficients for that variable. 
coefficients of the money variables. First, the price level may be affected only by large changes in the money supply. The positive coefficient of the trend term would then suggest that inflation persists over time. Second, a lack of data and incomplete model specification (as suggested in the above paragraph) may introduce an error-in-variables problem. This would explain why the time trend enters positively in the model, compensating for low coefficients on money variables. There is, however, no evidence that the coefficients would be only biased downward. In particular, the money-inflation relationship may not be stable over time.

Table 3. Long-Run Economic Relationships Between Money and Inflation

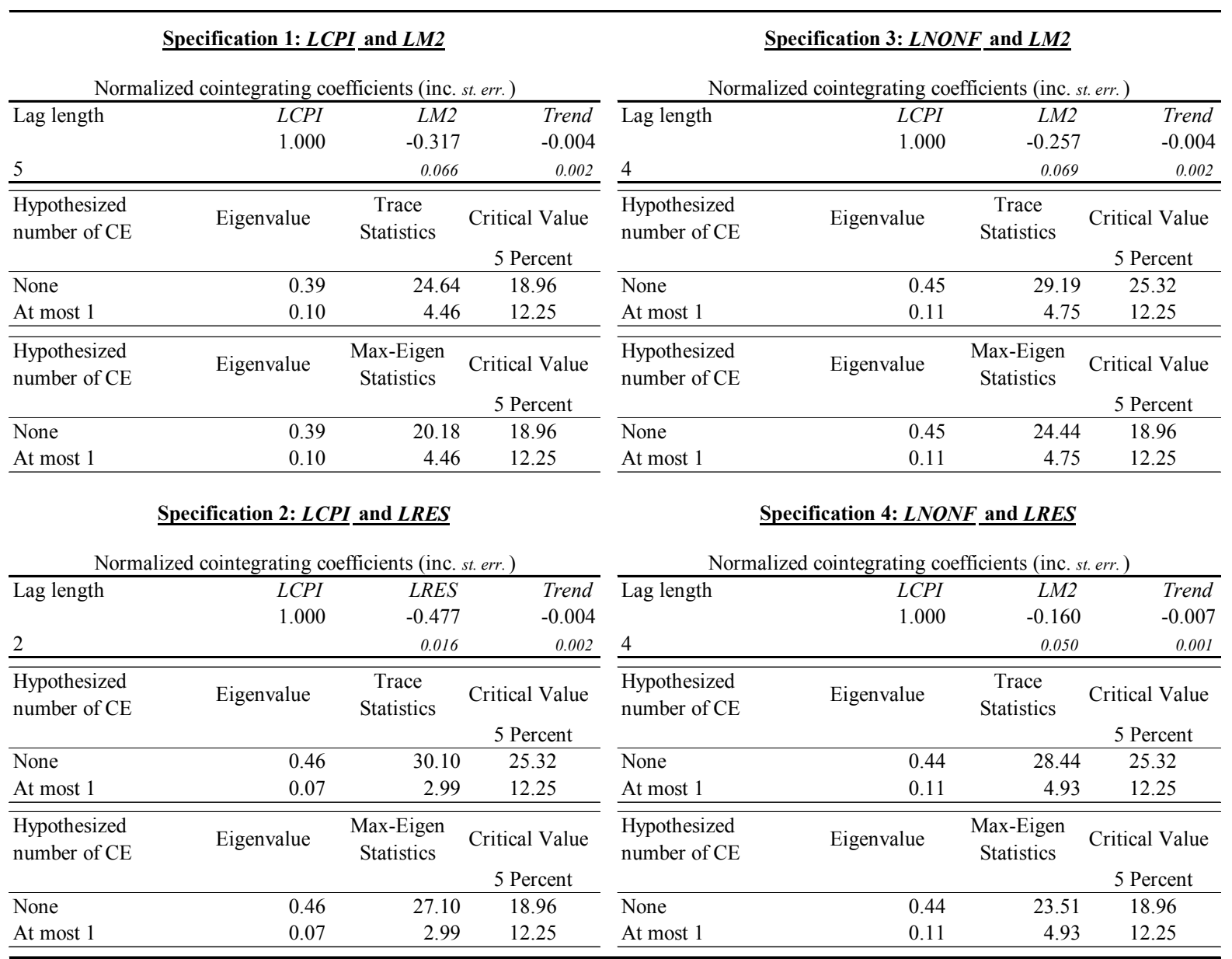

Note: In order to perform the cointegration tests, the series are assumed to have an intercept and a trend, restricted to lie inside the cointegration space.

We investigate further the long-term relationship between money and inflation by testing for the presence of structural breaks in the model. Chow's breakpoint test is used and requires the ex ante identification of periods to test for stability. Past inflation trends in Guinea suggest two potential breakpoints in the data. First, based on 12-month rates of inflation, a distinction may be drawn between the disinflationary period, December 1992-December 1997, and the subsequent period, March 1998-March 2003, when inflation remained controlled around lower rates. Second, 3-month growth rates for both inflation and the money variables suggest a rupture in the data in December 1999, with a period of greater 
volatility in the level of prices and of correlation between money and prices. A third potential breakpoint would be December 2002, the beginning of a period of accelerating inflation, combined with dramatic money growth. The experience is however too recent to test for the stability of the pass-through equations and long-run relationships.

The breakpoint Chow test fits the long-run relationships separately for each sub-sample and then compares the two sets of estimates. The $F$-statistic tests the null hypothesis of no structural break in the long-term relationship coefficient. The log-likelihood ratio statistics complement this test and follows an asymptotic chi-squared $\left(\aleph^{2}\right)$ distribution under the null hypothesis of no structural change. The results on the stability test for the four long-term relationships identified above are reported in Table 4.

Table 4. Structural Break Test (Chow Breakpoint Test)

\begin{tabular}{|c|c|c|c|c|}
\hline & $L C P I-L M 2$ & LCPI - LRes & $L N O N F-L M 2$ & LNONF - LRes \\
\hline \multicolumn{5}{|c|}{ Structural break from 1997: 4 onward } \\
\hline$F$-statistic & $6.11(0.0046)$ & $6.37(0.0037)$ & $1.80(0.1781)$ & $2.52(0.0926)$ \\
\hline Log likelihood ratio & $11.76(0.0028)$ & $12.20(0.0022)$ & $3.78(0.1511)$ & $5.21(0.0739)$ \\
\hline \multicolumn{5}{|c|}{ Structural break from 1999: 4 onward } \\
\hline$F$-statistic & $8.85(0.0006)$ & $3.70(0.0328)$ & $7.51(0.0016)$ & $1.93(0.1577)$ \\
\hline Log likelihood ratio & $16.21(0.0003)$ & $7.47(0.0239)$ & $14.06(0.0009)$ & $4.09(0.1323)$ \\
\hline
\end{tabular}

The null hypothesis of no structural change is decisively rejected for three of the four longrun relationships, for both periods, supporting the argument of a change in the relationship between money supply and inflation since 1992. When the long-run relationships are reestimated for the periods 1997:4-2003:1 and 1999:4-2003:1, a substantial increase in the money coefficients is observed (see Table 5). This confirms that the long-run pass-through between money and prices has become more significant in recent years, even though the results should be taken with caution given the very few degrees of freedom in the estimates.

Table 5. Long-Run Relationships Reestimated

$$
\begin{aligned}
& \underline{\mathbf{1 9 9 7}: 4-\mathbf{2 0 0 3 : 1}} \\
& L C P I=0.445 L M 2+0.005 \text { Trend } \\
& L C P I=0.544 L \text { Res }+0.006 \text { Trend } \\
& L N O N F=0.375 L M 2+0.004 \text { Trend } \\
& L N O N F=0.520 L \text { Res }+0.030 \text { Trend }
\end{aligned}
$$

\author{
1999:4-2003:1 \\ $L C P I=0.357 L M 2+0.004$ Trend \\ $L C P I=0.564$ Lres +0.006 Trend \\ $L N O N F=0.837 L M 2+0.007$ Trend \\ LNONF $=1.450$ Lres +0.043 Trend
}




\section{SHORT-RUN INFLATION DYNAMICS}

The dynamic version of the long-run relationship estimated in equation (2) can be specified as an error-correction model of the form:

$$
\Delta x_{t}=\mu+\sum_{i=1}^{k} \Gamma_{i} \Delta x_{t-i}+\alpha \beta^{\prime} x_{t-i}+\varepsilon_{t}
$$

This equation differs from a simple vector autoregressive model in first differences in the $\beta^{\prime} x_{t-i}$ term, called the error-correction term. The error-correction model approximates deviation from the equilibrium and estimates the short-run response necessary for the system to return to its equilibrium.

Table 6. Vector Error Correction Estimates for D(LCPI) and D(LNONF)

\begin{tabular}{|c|c|c|c|c|c|c|c|}
\hline & $\mathrm{D}(\mathrm{LCPI})$ & & $\mathrm{D}(\mathrm{LCPI})$ & & D(LNONF) & & $\mathrm{D}$ (LNONF) \\
\hline \multirow[t]{2}{*}{$\mathrm{ECM}$} & -0.604 & ECM & -0.622 & ECM & -0.733 & ECM & -0.667 \\
\hline & $0.171 * *$ & & $0.127 * *$ & & $0.146 * *$ & & $0.137 * *$ \\
\hline \multirow[t]{2}{*}{ D(LCPI(-1)) } & 0.198 & D(LCPI(-1)) & 0.070 & D(LNONF(-1)) & 0.404 & D(LNONF(-1)) & 0.336 \\
\hline & 0.195 & & 0.123 & & $0.168 * *$ & & $0.156 * *$ \\
\hline \multirow[t]{2}{*}{$\mathrm{D}(\mathrm{LCPI}(-2))$} & 0.091 & D(LCPI(-2)) & -0.200 & D(LNONF(-2)) & 0.305 & D(LNONF(-2)) & 0.109 \\
\hline & 0.201 & & 0.114 & & $0.165 *$ & & 0.149 \\
\hline \multirow[t]{2}{*}{$\mathrm{D}(\mathrm{LCPI}(-3))$} & 0.352 & D(LRES(-1)) & -0.049 & D(LNONF(-3)) & 0.611 & D(LNONF(-3)) & 0.506 \\
\hline & $0.170 * *$ & & 0.040 & & $0.151 * *$ & & $0.138 * *$ \\
\hline \multirow[t]{2}{*}{$\mathrm{D}(\mathrm{LCPI}(-4))$} & 0.375 & D(LRES(-2)) & -0.095 & D(LNONF(-4)) & 0.500 & D(LNONF(-4)) & 0.336 \\
\hline & $0.155 * *$ & & $0.037 * *$ & & $0.146 * *$ & & $0.136 * *$ \\
\hline \multirow[t]{2}{*}{$\mathrm{D}(\mathrm{LCPI}(-5))$} & 0.000 & $\mathrm{C}$ & 0.019 & D(LM2(-1)) & -0.168 & $\mathrm{D}(\operatorname{LRES}(-1))$ & -0.095 \\
\hline & 0.137 & & $0.003 * *$ & & $0.056 * *$ & & $0.043 * *$ \\
\hline \multirow[t]{2}{*}{ D(LM2(-1)) } & -0.093 & & & $\mathrm{D}(\mathrm{LM} 2(-2))$ & -0.126 & $\mathrm{D}(\operatorname{LRES}(-2))$ & -0.112 \\
\hline & 0.078 & & & & $0.049 * *$ & & $0.041 * *$ \\
\hline \multirow[t]{2}{*}{ D(LM2(-2)) } & -0.156 & & & $\mathrm{D}(\mathrm{LM} 2(-3))$ & -0.039 & $\mathrm{D}(\operatorname{LRES}(-3))$ & -0.021 \\
\hline & $0.072 * *$ & & & & 0.048 & & 0.040 \\
\hline \multirow[t]{2}{*}{$\mathrm{D}(\mathrm{LM} 2(-3))$} & -0.058 & & & $\mathrm{D}(\mathrm{LM} 2(-4))$ & -0.100 & $\mathrm{D}(\operatorname{LRES}(-4))$ & -0.080 \\
\hline & 0.062 & & & & $0.045 * *$ & & $0.038 * *$ \\
\hline \multirow[t]{2}{*}{$\mathrm{D}(\mathrm{LM} 2(-4))$} & -0.120 & & & $\mathrm{C}$ & 0.004 & $\mathrm{C}$ & 0.005 \\
\hline & $0.055 * *$ & & & & 0.005 & & 0.004 \\
\hline \multirow[t]{2}{*}{ D(LM2(-5)) } & -0.168 & & & & & & \\
\hline & $0.051 * *$ & & & & & & \\
\hline \multirow[t]{2}{*}{$\mathrm{C}$} & 0.017 & & & & & & \\
\hline & $0.005 * *$ & & & & & & \\
\hline$R$-squared & 0.622 & $R$-squared & 0.452 & $R$-squared & 0.563 & $R$-squared & 0.577 \\
\hline Adj. $R$-squared & 0.479 & Adj. $R$-squared & 0.380 & Adj. $R$-squared & 0.436 & Adj. $R$-squared & 0.455 \\
\hline Normality & $11.997 * *$ & Normality & $2.809 * *$ & Normality & 23.150 & Normality & $5.434 * *$ \\
\hline
\end{tabular}

Notes: t-statistics are reported in italics; ${ }^{*}$ indicates significance at 5 percent level, $*$ indicates significance at 10 percent level. Results for normality are the multivariate extensions of the Jarque-Bera residual normality tests, based on the Cholesky orthogonalization method. Except for one equations, we may not reject the hypothesis of multivariate normality at the 5 percent degree of confidence.

We estimate the error-correction model using the full information maximum likelihood. While the system estimates the error-correction equation for each of the two variables in the model, we report in Table 6 only the four error-correction equations corresponding to the inflation equation. In each of the four equations, the coefficient of the error-correction term is 
significant at the 5 percent level and varies in levels between -0.604 and -0.733 , suggesting that about two-thirds of the excess money supply is reabsorbed through inflation in each quarter. However, the suggested impact of lagged money growth is counterintuitive, with the model suggesting that acceleration of the rate of money growth results in a reduction in inflation. Finally, coefficients on lagged inflation are significant and positive (at varying lags depending on the variables entered in the model), suggesting that inflation is persistent over time.

Figure 4. Impulse Response Analysis on the Inflation Variables 1/
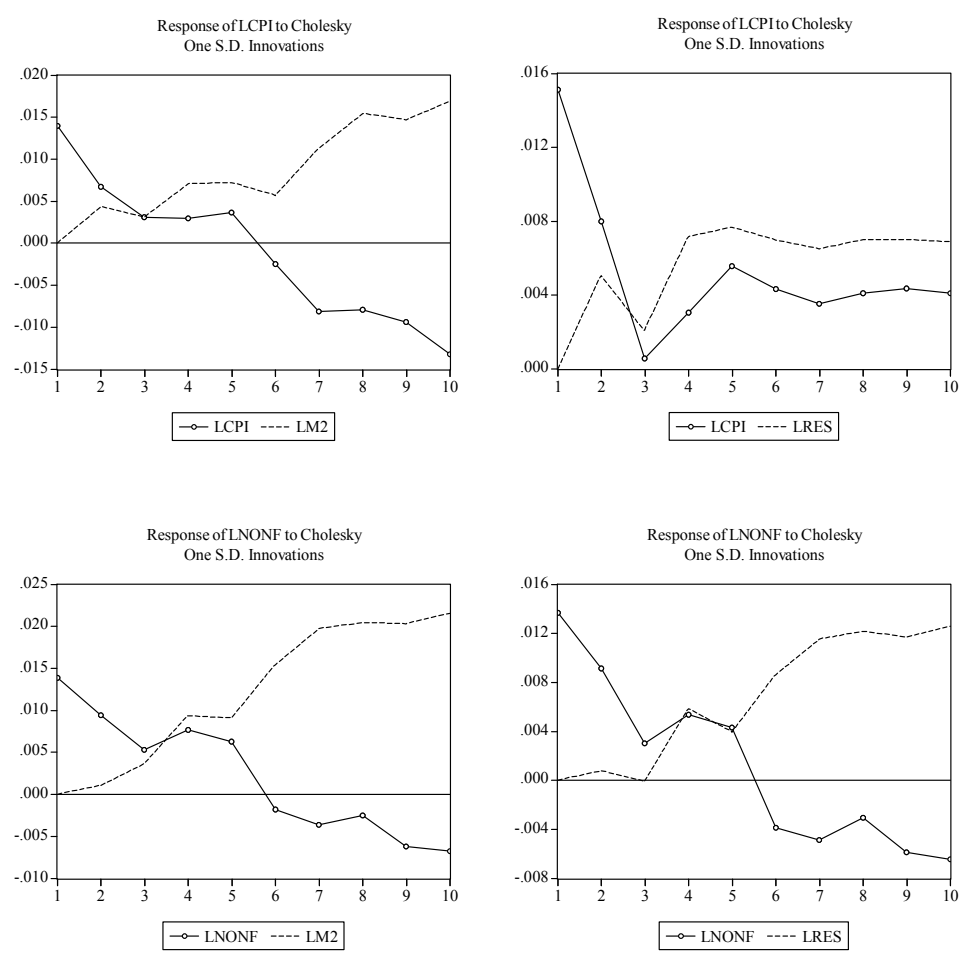

1/ Using the Cholesky decomposition factor.

The vector error-correction model estimates the dynamic impact of changes in the variables in the model. An impulse-response analysis traces the impact of a standardized shock to the $i$ th variable to all of the other endogenous variables in the model. The effect of a change in the monetary and the inflationary variable on current and future values of the inflation variable is represented in Figure 4. In response to a shock in money growth, inflation rises significantly over a period of about two years, after which it stabilizes at a higher level. This response is consistent with what was expected: the increase in the stock of broad money or reserve money resulting in a permanent increase in price levels. The impact of a contemporaneous shock in inflation on future values of inflation suggest an immediate jump in price levels, which decreases over time. After a time, between five and six periods, the impact turns negative, and leads to a reduction in inflation. This may suggest that an experience of high inflation may lead to a rapid policy response that eventually reduces the rate of inflation. This interpretation is supported by the experience in Guinea since 1991. It also confirms that there is a significant role for monetary policy in reducing inflation. 


\section{ConCluSION}

The findings in this paper support a long-term positive relationship between money and inflation:

- The long-run relationship between money and consumer prices is found to be statistically significant, and more so in recent years.

- Short-term dynamics are shown to accentuate the long-run impact. Impulse response analysis show that a shock in the money stock will have an increasing impact on inflation over two years and will stabilize at a higher level after that time.

The results are in line with the classical assertions about the links between the real and the monetary spheres - that is, that the price level is significantly affected by monetary policy, in the short run and the long run. They support previous findings from similar studies for other African countries. For example, Kuijs (1998) found that, in Nigeria, the difference between money supply and money demand determines the price level in the long run. The case of Madagascar, as documented by Sacerdoti and Xiao (2001), is comparable to Guinea's, with inflation adjusting to changes in the money supply relatively slowly and inflation inertia being strong. Country studies of Uganda (Nachega, 2001b), Kenya (Durevall and Ndung'u, 1999), and Cameroon (Nachega, 2001a) provide similar results. This suggests that the proposed framework could be usefully applied to other economies - in particular to countries where food constitutes a large share of the consumer basket and where monetary policy is volatile and expansionary to accommodate the fiscal stance.

From a policy perspective, both reserve money and broad money are found to have a significant impact on inflation over time. This finding suggests that monetary policy should focus on reserve money, which has the closer link to inflation. Active liquidity management (presently in the form of issuance of sterilization bills) is needed to meet reserve money targets. To prevent excessive broad money expansion, an adequate macroeconomic policy mix is required, including, notably, a sustainable fiscal policy. The financing of the government deficit through treasury bills, even though sounder than monetary financing, would lead to an expansion in net domestic assets and, hence, in broad money, with a substantial impact on price levels in the economy. 


\section{Appendix. Measures of Inflation and Early Signals in Guinea}

A common way to measure inflation is to use data on the year-on-year rate of change, sometimes complemented by the 12-month annual average rate of change. One-year, or 12month growth rates present a summary of the trends over the past 12 months, but reflect only partially the most recent changes in inflation and can therefore be misleading. Inflationary trends in Guinea over the past year, as reported in Table 7, are illustrative. The annualized one-month and three-month rates indicated as early as July 2002 the emergence of inflationary pressures, while the 12-month rates remained at low levels until October 2002. During the same period, monetary policy remained lax and failed to absorb the excess liquidity injected into the system. The one-month and three-month growth rates may provide adequate additional indicators to support early monetary policy responses.

Misleading information may arise because simple moving averages are very sensitive to shocks and outliers - often related to the price jumps between harvests. In Guinea, outliers in inflation series are frequent, and their impact is persistent in the published 12-month growth rates of inflation. To illustrate the argument, we correct the CPI index for outliers, and replace the monthly price change with the average of the previous and of the next month price changes. The lasting impact of a one-month price change is clear. For example, the 5 percent monthly increase in September 2000 - the largest monthly increase by far in the series - caused the 12-month rate of inflation to rise 4.8 percentage points higher than it would have been without the outlier observation for the next 11 month. ${ }^{13}$ In the same way, a base effect distorts 12-month inflation time series, when the drop (or increase) in the series is caused by the falling out of the 12-month average rate of the abnormally high (or low) rate observed in the 12th month before. In the Guinea data, this is observed most clearly in the reduction in the 12-month growth rate from 8.3 percent in August 2001 down to 3.4 percent in September 2001. One of the solutions proposed in the literature ${ }^{14}$ is to use the three-month growth rates, which take into account more accurately current inflation developments while reducing the amount of noise from the one-month growth rate.

${ }^{13}$ A similar phenomenon was identified by Maehle (2002).

${ }^{14}$ For example Blinder (1997) and Cecchetti (1997). 
Table 7. Guinea: Developments in the Overall CPI, January 2000 - March 2003

(In percent, unless otherwise indicated)

\begin{tabular}{|c|c|c|c|c|c|c|c|c|}
\hline & $\begin{array}{c}\text { Index } \\
(1991=100)\end{array}$ & $\begin{array}{c}\text { 12-Month } \\
\text { Growth Rate }\end{array}$ & $\begin{array}{c}\text { Average } \\
\text { Annual } \\
\text { Growth Rate }\end{array}$ & $\begin{array}{c}\text { 1-Month } \\
\text { Growth rate }\end{array}$ & $\begin{array}{c}\text { 1-Month } \\
\text { Growth rate } \\
\text { at Annualized } \\
\text { Rate }\end{array}$ & $\begin{array}{c}\text { 3-Month } \\
\text { Growth rate } \\
\text { at Annualized } \\
\text { Rate }\end{array}$ & $\begin{array}{l}\text { Corrected 12- } \\
\text { Month } \\
\text { Growth Rate }\end{array}$ & $\begin{array}{c}\text { Corrected 12- } \\
\text { Month } \\
\text { Growth Rate }\end{array}$ \\
\hline Jan-00 & 156.7 & 6.4 & 6.2 & -0.1 & -0.8 & 8.1 & 156.7 & 6.2 \\
\hline Feb-00 & 156.9 & 6.3 & 6.1 & 0.1 & 1.5 & 4.1 & 156.9 & 6.1 \\
\hline Mar-00 & 157 & 6.1 & 5.9 & 0.1 & 0.8 & 0.5 & 157.0 & 5.9 \\
\hline Apr-00 & 156.6 & 6.0 & 5.8 & -0.3 & -3.1 & -0.3 & 156.6 & 5.8 \\
\hline May-00 & 157 & 5.9 & 5.8 & 0.3 & 3.1 & 0.3 & 157.0 & 5.8 \\
\hline Jun-00 & 157.3 & 5.9 & 5.8 & 0.2 & 2.3 & 0.8 & 157.3 & 5.8 \\
\hline Jul-00 & 157.8 & 5.6 & 5.5 & 0.3 & 3.8 & 3.1 & 157.8 & 5.5 \\
\hline Aug-00 & 158.6 & 5.0 & 4.9 & 0.5 & 6.1 & 4.1 & 158.6 & 4.9 \\
\hline Sep-00 & 166.6 & 10.4 & 10.1 & 5.0 & 60.5 & 23.6 & 159.0 & 5.4 \\
\hline Oct-00 & 166.6 & 8.5 & 8.3 & 0.0 & 0.0 & 22.3 & 159.0 & 3.5 \\
\hline Nov-00 & 167.4 & 7.8 & 7.6 & 0.5 & 5.8 & 22.2 & 159.8 & 2.9 \\
\hline Dec-00 & 168.1 & 7.2 & 7.1 & 0.4 & 5.0 & 3.6 & 160.4 & 2.3 \\
\hline Jan-01 & 168.3 & 7.4 & 7.3 & 0.1 & 1.4 & 4.1 & 160.6 & 2.5 \\
\hline Feb-01 & 167.1 & 6.5 & 6.4 & -0.7 & -8.6 & -0.7 & 159.5 & 1.6 \\
\hline Mar-01 & 167.2 & 6.5 & 6.4 & 0.1 & 0.7 & -2.1 & 159.6 & 1.6 \\
\hline Apr-01 & 167.1 & 6.7 & 6.6 & -0.1 & -0.7 & -2.9 & 159.5 & 1.8 \\
\hline May-01 & 167.4 & 6.6 & 6.5 & 0.2 & 2.2 & 0.7 & 159.8 & 1.8 \\
\hline Jun-01 & 168.1 & 6.9 & 6.8 & 0.4 & 5.0 & 2.2 & 160.4 & 2.0 \\
\hline Jul-01 & 168.9 & 7.0 & 6.9 & 0.5 & 5.7 & 4.3 & 161.2 & 2.2 \\
\hline Aug-01 & 171.7 & 8.3 & 8.1 & 1.7 & 19.9 & 10.3 & 161.9 & 2.1 \\
\hline Sep-01 & 172.3 & 3.4 & 3.4 & 0.3 & 4.2 & 10.0 & 162.4 & 2.2 \\
\hline Oct-01 & 172.6 & 3.6 & 3.6 & 0.2 & 2.1 & 8.8 & 162.7 & 2.3 \\
\hline Nov-01 & 169.5 & 1.3 & 1.3 & -1.8 & -21.6 & -5.1 & 163.1 & 2.1 \\
\hline Dec-01 & 170 & 1.1 & 1.2 & 0.3 & 3.5 & -5.3 & 163.6 & 2.0 \\
\hline Jan-02 & 169.8 & 0.9 & 0.9 & -0.1 & -1.4 & -6.5 & 163.4 & 1.7 \\
\hline Feb-02 & 170.6 & 2.1 & 2.1 & 0.5 & 5.7 & 2.6 & 164.2 & 2.9 \\
\hline Mar-02 & 171 & 2.3 & 2.3 & 0.2 & 2.8 & 2.4 & 164.5 & 3.1 \\
\hline Apr-02 & 171 & 2.3 & 2.3 & 0.0 & 0.0 & 2.8 & 164.5 & 3.2 \\
\hline May-02 & 171.6 & 2.5 & 2.5 & 0.4 & 4.2 & 2.3 & 165.1 & 3.3 \\
\hline Jun-02 & 172.5 & 2.6 & 2.6 & 0.5 & 6.3 & 3.5 & 166.0 & 3.5 \\
\hline Jul-02 & 174.7 & 3.4 & 3.4 & 1.3 & 15.3 & 8.7 & 166.9 & 3.5 \\
\hline Aug-02 & 175.7 & 2.3 & 2.3 & 0.6 & 6.9 & 9.6 & 167.8 & 3.7 \\
\hline Sep-02 & 176.5 & 2.4 & 2.4 & 0.5 & 5.5 & 9.3 & 168.6 & 3.8 \\
\hline Oct-02 & 177.2 & 2.7 & 2.7 & 0.4 & 4.8 & 5.7 & 169.3 & 4.0 \\
\hline Nov-02 & 179.3 & 5.8 & 5.6 & 1.2 & 14.2 & 8.2 & 171.3 & 5.0 \\
\hline Dec-02 & 180.4 & 6.1 & 6.0 & 0.6 & 7.4 & 8.8 & 172.3 & 5.4 \\
\hline Jan-03 & 182.3 & 7.4 & 7.1 & 1.1 & 12.6 & 11.5 & 174.1 & 6.6 \\
\hline Feb-03 & 184 & 7.9 & 7.6 & 0.9 & 11.2 & 10.5 & 175.8 & 7.1 \\
\hline Mar-03 & 188.7 & 10.4 & 9.9 & 2.6 & 30.7 & 18.4 & 180.3 & 9.6 \\
\hline
\end{tabular}

Sources: Guinean authorities; and staff calculations. 


\section{References}

Blinder, A., 1997, “Commentary,” Federal Reserve Bank of St. Louis Review, (May/June), pp. 157-60.

Cecchetti, S., 1997, "Measuring Short-Run Inflation for Central Bankers," Federal Reserve Bank of St. Louis Review, (May/June), pp. 143-55.

Dickey, D., and W.A. Fuller, 1981, "Likelihood Ratio Statistics for Autoregressive Time Series with a Unit Root," Econometrica, Vol. 49 (July), pp.1057-72.

Durevall, D., and N.S. Ndung'u, 1999, “A Dynamic Model of Inflation for Kenya, 19741996,” IMF Working Paper 99/97 (Washington: International Monetary Fund).

Johansen, S., 1988, "Statistical Analysis of Cointegration Vectors," Journal of Economic Dynamics and Control, Vol. 12 (June-September), pp. 231-54.

Kuijs, L., 1998, “Determinants of Inflation, Exchange Rate, and Output in Nigeria," IMF Working Paper 98/160 (Washington: International Monetary Fund).

Maehle, N., 2002, "Inflation in Kenya-Signal Extraction for Policy Purposes," Kenya: Selected Issues and Statistical Appendix, IMF Country Report No. 02/84 (Washington: International Monetary Fund).

Mankiw, N.G., 2003, Macroeconomics, New York: Worth Publishers.

Nachega, J-C., 2001a, “A Cointegration Analysis of Broad Money Demand in Cameroon,” IMF Working Paper 01/26 (Washington: International Monetary Fund). , 2001b, "Financial Liberalization, Money Demand and Inflation in Uganda," IMF Working Paper 01/118 (Washington: International Monetary Fund).

Sacerdoti, E., and Y. Xiao, 2001, “Inflation Dynamics in Madagascar, 1971-2000,” IMF Working Paper 01/168 (Washington: International Monetary Fund).

Sriram, S., 2000, “A Survey of Recent Empirical Money Demand Studies,” IMF Staff Papers, Vol. 47, no. 3, pp. 334-65. 